\title{
Open Journal System in the Era of Paperless Papers
}

\author{
Tayyaba Gul Malik ${ }^{1}$ \\ ${ }^{1}$ Department of Ophthalmology, Rashid Latif Medical College, Lahore
}

With the start of 2020, we have entered a new decade with the never-ending challenges of the developing world. One of the challenges is the barrier against access to the latest scientific knowledge. To cope with this barrier, it is indispensable that the current scientific literature should be made freely available to the resource-constrained countries like Pakistan. Pakistan Journal of Ophthalmology has taken a step forward and joined the club of open access journals through "Open Journal System" (OJS).

To understand the importance of OJS let us turn the wheel of time backwards. Imagine the world where the only source of documentation of knowledge was wood painting. Centuries passed by and in 100 BC, Chinese invented paper and in $105 \mathrm{AD}$ the first ever papermaking industry was started. In mid fifteenth century, Gutenberg invented a printing press, which made possible the more consistent form of printed copies than the professional copyist $\mathrm{did}^{1,2}$. It was a revolution in the scientific world where the scientists were called natural philosophers. In 1665, another milestone was reached with the creation of first scientific journal "the Journal des Sçavans" and the "Philosophical Transactions" which were published in France and in England respectively and simultaneously ${ }^{3}$. Sixth of March 2020 will be the $355^{\text {th }}$ anniversary of the creation of scientific journals. Before that, the scientists had personal correspondence through letters, which was made more systematic and structured with the publishing of these journals. It led to the process of peer review for development and progression of scientific knowledge.

How to Cite this Article: Malik TG. Open Journal System in the Era of Paperless Papers. Pak J Ophthalmol. 2020; 36 (1): 1-2.

DOI: https://doi.org/10.36351/pjo.v36i1.908

Correspondence to: Tayyaba Gul Malik

Rashid Latif Medical College, Lahore

Email:tayyabam@yahoo.com
This not only resulted in wider and more structured propagation of knowledge but also recording and archiving was made more systematic ${ }^{4}$. Another breakthrough occurred in 1983 with the advent of 'network of networks' now called internet. Development of worldwide web in 1990 brought another spin, which paralleled the Gutenberg's discovery of printing press, if not exceeded it. This was followed by adoption of the concept of paperless office (although the term was already coined even before the development of internet $)^{5}$. The idea was to end reliance on paper and to adopt a digital approach. This concept helped in saving time, space and money, improving efficiency and streamlining the workflow. From submission of research article in hard copies to the use of online platform, there is a huge hidden effort, which has done more than just saving the trees.

After the digitalization of the research papers, now is the era of open access journals. By definition, Open access (OA) is a mechanism by which research outputs are distributed online, free of cost and free of other access barriers. A stricter definition would be the removal or reduction of barriers to copying or reuse by an open license ${ }^{6}$. Time has shown that open access has increased the citations of articles ${ }^{7}$. Another advantage of open access journal is the capability to record views, downloads and citations of articles. Although increased citations are not a criterion to indicate the importance and influence of the particular research paper in the concerned field but it does indicate the impact a particular article has in a discipline. Later surveys provided further evidence that open access journals had increased readership as compared to the similar work without open access ${ }^{8,9}$.

Keeping in view the convenience, capability, efficiency and increased readability by the use of open access to the journals, Public Knowledge Project (PKP) launched Open Journal Systems (OJS) in 2002. It is a free online journal publishing and managing software. It was an undergraduate computer science 
project at the University of British Columbia (UBC) in Vancouver, Canada, under the direction of John Willinsky, with subsequent participation by Simon Fraser University Library, the Canadian Centre for Studies in Publishing, and Stanford University. The idea was to explore the feasibility of journals to publish their content online and to see the consequences. OJS is currently in version 3.1.2.4 (Pakistan Journal of Ophthalmology is using version 3.1.1.4). In version 2.3 , there are 17 languages with complete translations ${ }^{10}$. It was the convenience and the practicality of this system that within one and a half decade there were more than 8,000 journals worldwide, which were using $\operatorname{OJS}^{11}$. By 2018, 9412 journals were using OJS. Among these, 200 journals were in Canada, 674 in USA, 1656 in Brazil and 173 in Russia. In 2008, only 11 journals were making use of OJS in India and Pakistan. Exactly after 10 years, in 2018, this number has increased to 139 in India and still 13 in Pakistan ${ }^{12}$.

Once this system was disseminated throughout the whole world, PKP decided to make criteria for journals to be included in the count of OJS. It was determined that an OJS journal must have at least 10 articles published in a single year to be officially included in the count of OJS journals.

Every change brings problems associated with it, which needs to be tackled. Scientific content is the most valuable treasure of this time and it needs to be protected for the coming generations. With a complete transition to the electronic-only open access journals, there arose the need for an emergency preservation strategy for the journal contents. The idea was to prevent the disaster of knowledge famine in case of system failure or human error. Stanford University developed the open source LOCKSS project (Lots of Copies Keeps Stuff Safe). LOCKSS comprise of servers, which are distributed and maintained throughout the world in different libraries to collect and secure the journal content at various places. LOCKSS and CLOCKSS (Controlled Lots of Copies Keeps Stuff Safe) are important features of OJS. By acquiring this archiving facility, the data can be saved for hundreds of years.

With shifting to OJS, it is now possible to manage the workflow starting from submission of article, multiple rounds of peer review, revision after review, copy editing, publishing, making articles' availability online and indexing. The whole process is managed by different individuals playing different roles online; journal manager, editor, reviewer, author, and reader. Journal subscription is also controlled by a subscription management component. With all these benefits, the time has come to break the "inertia" of resisting change and to move forward to bridge the gap of knowledge, which exists between the developed and developing countries.

\section{Conflict of Interest}

None.

\section{REFERENCES}

1. deSolla Price DJ. Little Science, Big Science. New York: Columbia University Press; 1963.

2. Haustein S. Multidimensional journal evaluation. Analyzing scientific periodicals beyond the impact factor. Berlin/Boston: De Gruyter Saur; 2012.

3. Tenopir C, King DW. The growth of journals publishing. In Cope B, Phillips A, editors. The Future of the Academic Journal. Oxford: Chandos Publishing. 2009: 105-123.

4. Zuckerman H, Merton RK. Patterns of evaluation in science-institutionalization, structure and functions of referee systems. Minerva. 1971; 9 (1): 66-100.

5. The Paperless Office Trademark Registration, United States Patent and Trademark Office. The Office of the Future. Business Week, 1975; 1975:48-70.

6. Peter S. Open Access Overview, Focusing on open access to peer-reviewed research articles and their preprints. MIT Press; 2012. Available from: http://legacy.earlham.edu/ peters/fos/overview.htm

7. Alma S. "Policy guidelines for the development and promotion of open access". UNESCO. 2012.

8. Harnad S, Brody T, Vallieres F, Carr L, Hitchcock S, Gingras Y, Oppenheim C, Hajjem C, Hilf E. The access/impact problem and the Green and Gold roads to open access: An update. Serials Review 2008; 34 (1): 36-40. http://eprints.ecs.soton.ac.uk/15852

9. Hitchcock $\mathbf{S}$. The effect of open access and downloads ('hits') on citation impact: A bibliography of studies. Unpublished paper. Open Citation Project, 2009. Available from:

http://opcit.eprints.org/oacitationbiblio.html

10. OJS Languages. Public knowledge project. Retrieved 21 August 2013. Available from: https://pkp.sfu.ca/contributors/translation/

11. OJS Stats. Public Knowledge Project. Retrieved 20 October2015. Available from: .https://pkp.sfu.ca/ojs/ojs-usage/ojs-stats/

12. OJS Map. Public Knowledge project. Retrieved 20 October2015. Available from:

https://pkp.sfu.ca/ojs/ojs-usage/ojs-map 